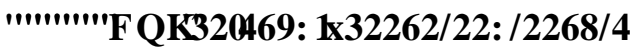

\title{
METHODS OF RELIABILITY INDEX DETERMINATION CONCERNING MUNICIPAL WATER QUALITY
}

\section{METODYKA OKREŚLANIA WSKAŹNIKÓW NIEZAWODNOŚCI WZGLĘDEM JAKOŚCI WODY WODOCIĄGOWEJ}

\author{
Janusz Ryszard Rak \\ Faculty of Civil and Environmental Engineering \\ Department of Water Supply and Sewage Systems \\ Rzeszów University of Technology \\ Al. Powstańców Warszawy 6, 35-959 Rzeszów \\ Wydział Budownictwa i Inżynierii Środowiska \\ Katedra Zaopatrzenia w Wodę i Odprowadzania Ścieków \\ Politechnika Rzeszowska \\ Al. Powstańców Warszawy 6, 35-959 Rzeszów \\ e-mail: rakjan@prz.rzeszow.pl
}

\begin{abstract}
Two - parametric method was used for evaluating a reliability of Water Treatment Plant, making use of an availability - K and the Mean Down Time - T. It has been developed a method of defininitioning the reliability indexes for drinking water in an aspect of its physical and chemical quality.
\end{abstract}

Keywords: water quality, reliability indexes

Streszczenie: Do oceny niezawodności Zakładu Uzdatniania Wody zastosowano metodę dwuparametryczna, wykorzystując wskaźnik $\mathrm{K}$ i średni czas naprawy $\mathrm{T}$. Opracowano metodę określania wskaźników niezawodności dla wody do spożycia w aspekcie jej fizyczno-chemicznej jakości.

Słowa kluczowe: jakość wody, wskaźniki niezawodności 


\section{METHODS OF RELIABILITY INDEX DETERMINATION CONCERNING MUNICIPAL WATER QUALITY}

\section{Introduction}

Drinking water from public water-pipe should be supplied to consumers in a sufficient quantity, should have an appropriate quality and a required pressure. The threshold values of the acceptable water pollution concentration given in a standard of quality allow to determine water suitability for consumption and for other needs [1] [5]. In most cases, however, the technological processes connected with water treatment do not take into account the extreme situations, in which the existing or designed water treatment process does not guarantee, for some period of time, that the requirements given in a standard of quality are met [3]. The extreme situations occur when the following events take place:

- periodical deterioration of raw water quality, for which the water treatment technological process is not prepared,

- failures of particular devices operating in the given technological procedures of water treatment.

In such cases bad water quality can cause that some restrictions in water intake or break in water supply are imposed.

If it is impossible to eliminate the occurrence of random, as a rule, periods of time when the standard values for treated water quality are exceeded for a short time, which, as operating practice shows, happens very often, it is necessary to implement restrictions for the duration and frequency of such failures. At the same time the limits of standard values excess for drinking water quality must be established. The introduction of such criteria will create a base for the additional protection [2]. The main aim of the presented method is to reduce the number of the situations in which treated water in water pipe has, for short periods of time, the unsuitable quality in relation to the standard of quality, and it has slightly higher, that is over normative, concentration of pollution, and, at the same time, to reduce the duration of such state. 


\section{The method of reliability index determination for drinking water concerning its physical and chemical quality}

\subsection{Assumptions of the method}

As a criterion for a drinking water pollution the concentration of pollution corresponding to the particular physical and chemical indexes of water composition, has been taken. Next the indexes included in Polish binding standard were divided into three groups, according to their harmfulness for human body. [3] [4].

The group A comprises the indexes that determine drinking water suitability. It includes, among others, colour, turbidity, iron, manganese, sulphate and chloride, for which we assume that periodic and limited excess of standard values is not the threat to human health.

The group B comprises the indexes that are essential as far as the threat to human health in concerned. There are, among others, forms of nitrogen and phosphorus, fluorides, ChZT, $\mathrm{pH}$.

The group $\mathrm{C}$ comprises the indexes that determine the toxic threat to human body. There are, among others, heavy metals, phenol, cyanides, DDT and its metabolites.

As one can see, the indexes in the group A concern pollution that is the least harmful for human body, while the indexes in the group $\mathrm{C}$ comprise substances which have cancerogenic impact on living things.

For all the indexes included in the discussed groups one common notion of the index for the situation when the standard of drinking water quality is exceeded, has been introduced and marked W. It is a criterion to estimate the Water Treatment Plant (WTP) reliability concerning drinking water quality.

This index has been defined as follows:

$W=\frac{S-S_{n o r}}{S_{\max }-S_{n o r}}$

where:

W - the index showing that drinking water quality standard is exceeded (related to the particular physical and chemical water index),

$\mathrm{S}$ - a real, measured concentration of the given physical and chemical drinking water index, higher than value given in Polish binding standard, 
$\mathrm{S}_{\max }$ - the maximum acceptable concentration of the given physical and chemical drinking water index, according to data given by the National Institute of Hygiene - ("Criteria of tolerance for the presence of chemical substances in drinking water and the amount of the indicatory microorganisms from 1978"),

$\mathrm{S}_{\text {nor }}$ - an acceptable concentration of the given physical and chemical drinking water index, according to the regulation [5].

It was assumed from the definition that for:

$\begin{array}{ll}\mathrm{S} \leq \mathrm{S}_{\text {nor }} & \mathrm{W}=0, \\ \mathrm{~S} \geq \mathrm{S}_{\max } & \mathrm{W}=1 .\end{array}$

The acceptable values $\mathrm{W}$ are within the range 0 to 1 , that is:

- $\mathrm{W}=0$ - water quality is satisfying, water parameters are better than the threshold values given by the standard,

- $0<\mathrm{W}<1$ - water quality does not meet standard requirements, however short periods of water with such quality are permitted, duration of such state is limited and determined in the further part of this work,

- $\mathrm{W}=1.0$ - water quality is not acceptable and there is an absolute necessity to shut down the intake and the WTP, so that consumers cannot use this water.

It is especially difficult to establish concentrations $\mathrm{S}_{\max }$ for people. The harmful dose depends on many biological features of human body, among others, on the degree of habit, congenital susceptibility or immunity, speed of absorption. It seems that concentration values $S_{\max }$, taken according to the mentioned above NIH instruction, are very safe, assuming that a man consumes $2.5 \mathrm{dm}^{3}$ of water per 24 hours and the time of water consumption is limited.

\subsection{Method description}

In table 1 the proposal of water- pipes division into the categories, with regard to quality reliability of drinking water and water used in household physical and chemical composition, is presented.

The probability that the concentration of pollution will exceed standard concentration is different for various degrees of this excess. The presented method allows to take into account different degrees of standard concentration excesses and weights, which are the probabilities that such excesses will occur. 
Considerations were carried out with reference to time unit 1 year. The degree of standard concentration excess is determined by the index W, showing that drinking water quality standard is exceeded, whose the threshold values were assumed arbitrarily. . In the method the frequencies $C_{i}$ of the occurrence of periods in which the threshold values $\mathrm{W}_{\mathrm{p}}\left(\mathrm{W}_{\mathrm{p}}=0.05\right.$, $0.1,0.3,0.5,0.7)$ can appear, were assumed. The probability of the occurrence of such periods can be determined from the formula:

$$
P_{i}=\frac{C_{i} \cdot T_{i}}{365}
$$

where:

$\mathrm{i}$ - the successive number of the analysed period in which values $0<\mathrm{W}_{\mathrm{i}}<$ 1.0 occur, $i=1,2, \ldots$,

$\mathrm{T}_{\mathrm{i}}-$ duration of period $\mathrm{i}$.

For the states in which condition $\mathrm{W}=0$ is met, that is for the periods in which the given index with relation to standard is not exceeded, we can write:

$$
P_{0}=1-\sum_{i} P_{i}
$$

The factor which presents WTP unreliability, referred to quality of water delivered to municipal water pipe, is the concentration of the given index of pollution over the standard value and is indirectly determined by the value $\mathrm{W}$. The generalized unreliability is determined by the ratio of the expected exceed value of the index $\mathrm{W}$ (cases when $0<\mathrm{W}<1$ ), marked as $\mathrm{E}(\mathrm{W})$, to the boundary exceed value, i.e. for $\mathrm{W}=1$ and is:

$$
\mathrm{U}_{\mathrm{u}}=\mathrm{E}(\mathrm{W})
$$

Respectively, the generalized reliability index is

$$
K_{u}=1-U_{u}
$$

and 
$W(\underline{W})=\frac{\sum_{i=1}^{2} P_{i} W_{i}}{\sum_{i=0}^{2} P_{i}} ; i=0,1,2$

The $K_{u}$ values calculated in this way are presented in table 1 . From the engineering point of view it is interesting to know the probability that WTP will deliver water having quality in accordance with the standard, at any time. This value concerns the case when $\mathrm{W}=0$ and it is equal $\mathrm{P}_{0}$.

We can interpret the information given in table 1 in the following way (Fig.1). Let us consider the category I, computational case A and $0<\mathrm{W} \leq$ 0,3 . The exceed of the standard value of the considered pollution from the group $\mathrm{A}$, located within the range $0<\mathrm{W} \leq 0,3$. can occur not more often than 10 times a year and the duration of each such case cannot exceed 8 hours. The index $\mathrm{W}$ means the threshold value $\mathrm{W}_{\mathrm{p}}=0.3$ and $\mathrm{P}_{1}$ means the probability that all cases will take place. The value $\mathrm{K}_{\text {udop }}$ is related to whole group of cases, thus for $\mathrm{W}=0,0<\mathrm{W} \leq 0,3$ and $0,3<\mathrm{W} \leq 0,5$. To use the table it is necessary to calculate the values of indexes $\mathrm{K}_{\mathrm{u}}$ and $\mathrm{P}_{0}$ for every WTP and to check if the inequality given below is satisfied:

$K \geq K_{w}$

where:

$\mathrm{K}$ - considered index $\mathrm{K}_{\mathrm{u}}$ or $\mathrm{P}_{0}$ (calculated separately for WTP),

$\mathrm{K}_{\mathrm{w}}$-its acceptable value according to the table ( $\left.\mathrm{K}_{\mathrm{udop} .}, \mathrm{P}_{\text {0dop. }}, \mathrm{P}_{\text {dop. }}\right)$.

If the inequality (7) is not satisfied then WTP does not meet the proposed values and should be modernized. The alternative solution is to introduce in WTP suitable services which are capable of reacting fast in case when the standard conditions are violated. In such cases those services would decide about temporary WTP shut down. 


\begin{tabular}{|c|c|c|c|c|c|c|c|c|c|c|c|}
\hline \multirow{3}{*}{ 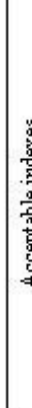 } & 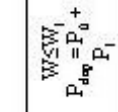 & $\Rightarrow$ & 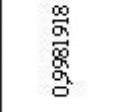 & $\begin{array}{l}\text { g } \\
\text { \% } \\
\text { g. }\end{array}$ & ' & 夏 & $\begin{array}{l}\text { g } \\
\text { g. } \\
\text { g: } \\
\text { g. }\end{array}$ & ' & 蒙 & $\begin{array}{l}8 \\
\text { 量 } \\
\text { 总 } \\
\text { : }\end{array}$ & ' \\
\hline & $\begin{array}{l}\text { II } \\
\text { s. }\end{array}$ & 9 & $\begin{array}{l}\tilde{G} \\
\overline{8} \\
\text { \% } \\
\text { 口. }\end{array}$ & $\begin{array}{l}\text { 离 } \\
\text { 产 } \\
\text { o. }\end{array}$ & 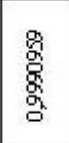 & 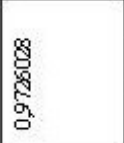 & 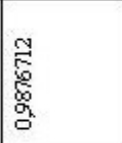 & $\begin{array}{l}\text { 畐 } \\
\text { 多 } \\
\text { 品 }\end{array}$ & 总 & $\begin{array}{l}\text { g } \\
\widetilde{5} \\
\text { \% }\end{array}$ & $\begin{array}{l}8 \\
\text { 思 } \\
\text { 品 }\end{array}$ \\
\hline & $4^{8}$ & $\alpha$ & 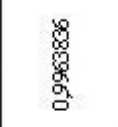 & $\begin{array}{l}5 \\
\text { g } \\
\text { g. }\end{array}$ & $\begin{array}{l}\frac{9}{0} \\
\frac{8}{8} \\
\frac{g}{\circ}\end{array}$ & $\begin{array}{l}\overrightarrow{\mathrm{g}} \\
\mathrm{g}\end{array}$ & $\begin{array}{l}\text { g } \\
\text { gू } \\
\text { g. }\end{array}$ & 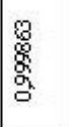 & $\begin{array}{l}9 \\
6 \\
g \\
g \\
\sigma\end{array}$ & 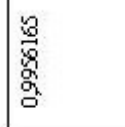 & $\begin{array}{l}\mathscr{8} \\
\text { 罗 } \\
\text { g. }\end{array}$ \\
\hline & 5 & $\infty$ & 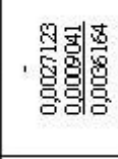 & ' & , 害 & 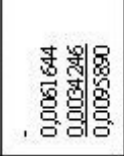 & 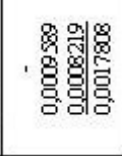 & ' & 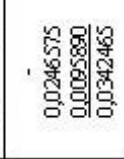 & ' & 喾 \\
\hline & 管 & $r$ & 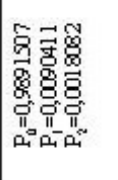 & 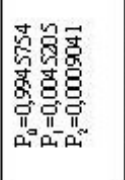 & 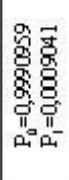 & 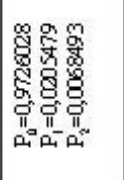 & 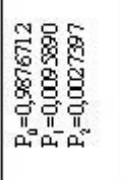 & 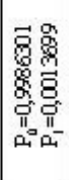 & 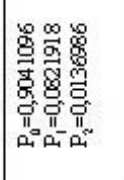 & 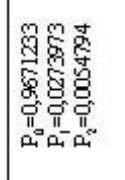 & 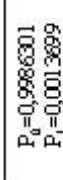 \\
\hline & $\mathrm{s}^{-}$ & 6 & 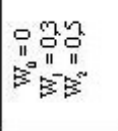 & 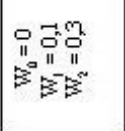 & 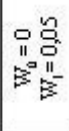 & 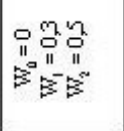 & 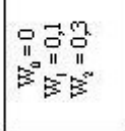 & 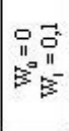 & 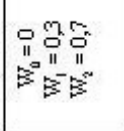 & 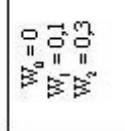 & 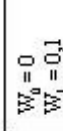 \\
\hline & $\mathrm{E}^{-}$ & $n$ & , p.: & , & . ․․ㅁ & 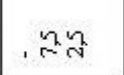 & $m_{1}^{2}=$ & . & , 品 &,$g_{N}$ & .8 \\
\hline & Fid & $\theta$ & 씀 & . ్ㅡㅁ & . & . 2. & . & . & $\rightarrow \rightarrow$ & $\rightarrow \rightarrow$ & .2 \\
\hline & $v-|| \begin{array}{l}\mathbf{2} \\
\end{array}$ & $m$ & $19 \mathrm{~N}$ & $n-$ & $1-$ & $\therefore n$ & $m n$ & . - & , $\mathrm{m}_{n}$ & , $9 \mathrm{~N}$ & . \\
\hline & 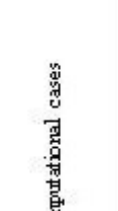 & $N$ & 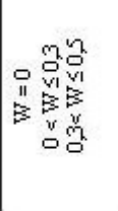 & 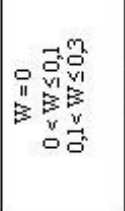 & 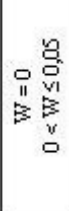 & 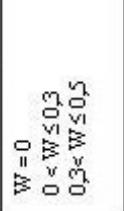 & 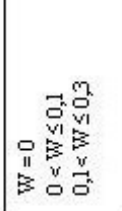 & 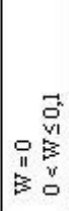 & 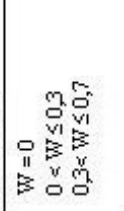 & 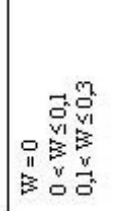 & 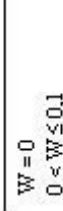 \\
\hline & 8 & & $0 \rightarrow n$ & $0-4$ & $0-1$ & $0 \rightarrow \mathrm{N}$ & $0 \rightarrow c$ & $0-$ & $0 \rightarrow c$ & $0-n$ & $0-$ \\
\hline & & & $\Rightarrow$ & Ф & 0 & $\Rightarrow$ & Ф & 0 & $\Rightarrow$ & Ф & 0 \\
\hline & 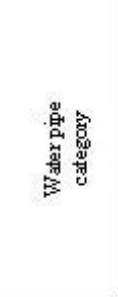 & -1 & 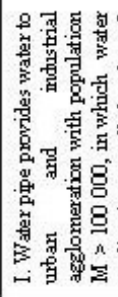 & & & 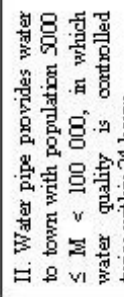 & & & 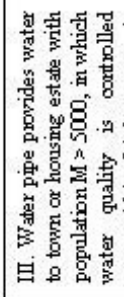 & 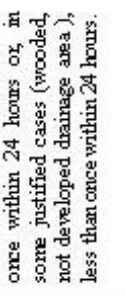 & \\
\hline
\end{tabular}




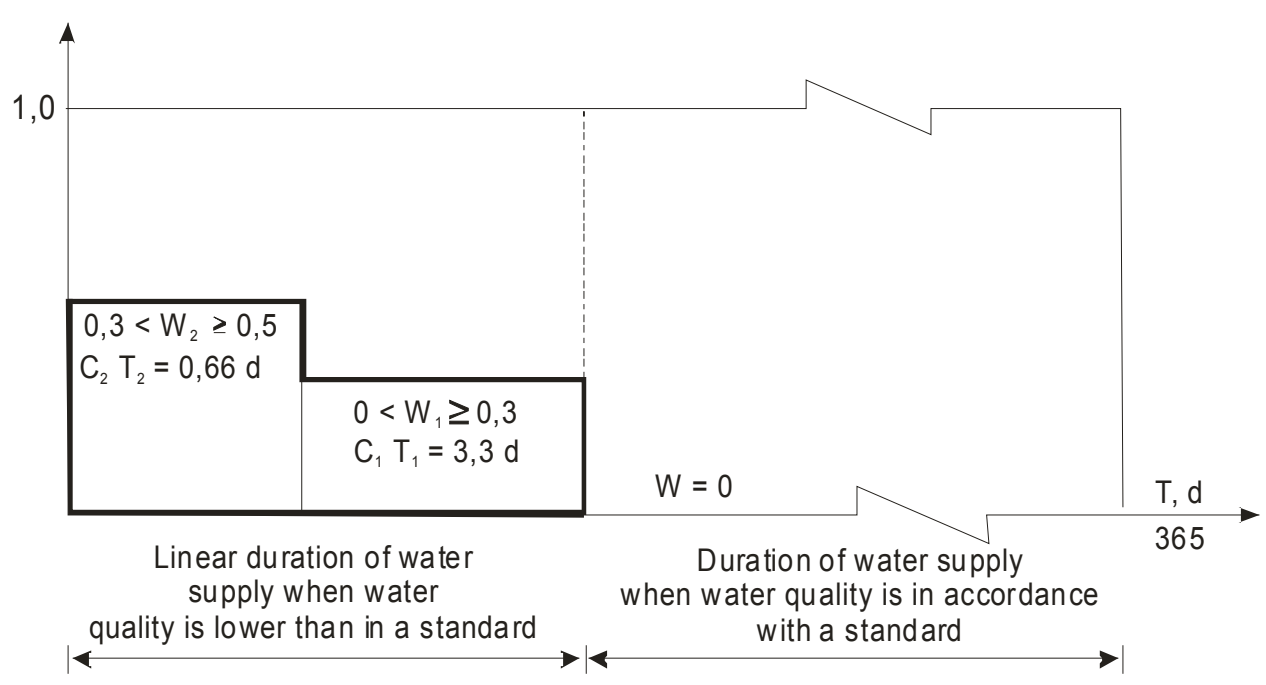

Fig. 1. Histogram of frequency of the occurrence of water quality states for the category IA, according to the proposed division.

\section{Conclusions}

- The objective reality in WTP operating are different types of undesirable events which cause the deterioration of water quality ( final product) and lower the level of reliability for water provided by public water pipe, and sometimes have a significant impact on water consumers safety.

- The idea presented here does not diminish the importance of water quality standard, which, verified during many years of usage, seems to be justified, which does not change the fact that it expresses current trends and it will certainly be corrected as the identification of the whole problem will be better. It seems that the introduction of the proposed development of the existing standard would become an impulse to:

- using more flexible technologies and some reserved power in WTP,

- using more effective and more frequent water quality control to ensure that conditions given in table 1 will be satisfied. The values of indexes presented in table 1 should be treated as the first attempt to execute the task presented is such way. 


\section{References}

1. Barański B., Szymczak W., i inni: Podstawy metod oceny ryzyka zdrowotnego. Wydawnictwo Instytutu Medycyny Pracy. Łódź, 1995 r.

2. Brandowski A.: Koncepcja nauki o bezpieczeństwie. Zagadnienia Eksploatacji Maszyn. Wydawnictwo. PAN, z. 3(95), 1993, s. 261-279.

3. Rak J.: Niezawodność systemu uzdatniania wód powierzchniowych. Zeszyty Naukowe Politechniki Rzeszowskiej, seria Budownictwo i Inżynieria Środowiska. z. 20. Oficyna Wydawnicza Politechniki Rzeszowskiej, Rzeszów, 1993 r.

4. Rak J.: Metoda szacowania ryzyka globalnego skażenia wody wodociqgowej. Gaz, Woda i Technika Sanitarna nr 4/2007. Wydawnictwo SIGMA-NOT, Warszawa, s. 6-9.

5. Rozporządzenie Ministra Zdrowia z dnia 29 marca 2007 r. w sprawie jakości wody przeznaczonej do spożycia przez ludzi. Dz. U. 07.61.417 z 6 kwietnia 2007 r. 


\section{METODYKA OKREŚLANIA WSKAŹNIKÓW NIEZA- WODNOŚCI WZGLĘDEM JAKOŚCI WODY WODOCIĄGOWEJ}

\section{Wprowadzenie}

Woda do spożycia powinna być dostarczana do użytkowników wodociagu w dostatecznej ilości o odpowiedniej jakości i pod wymaganym ciśnieniem. Podawane w normatywach wartości progowe dopuszczalnych stężeń zanieczyszczeń wody pozwalają określić jej przydatność do spożycia i dla potrzeb gospodarczych [1] [5]. Procesy technologiczne związane $\mathrm{z}$ uzdatnianiem wody w przeważającej liczbie przypadków nie uwzględniają jednak sytuacji ekstremalnych, w których projektowany bądź istniejący proces uzdatniania wody okresowo nie gwarantuje spełnienia wymagań określonych przez normatyw jej jakości [3]. Sytuacje ekstremalne zdarzają się w wypadku:

- okresowego pogorszenia jakości wody surowej na które nie jest przygotowany proces technologiczny uzdatniania wody,

- awarii poszczególnych urządzeń obsługujących dane operacje technologiczne uzdatniania wody.

W takich sytuacjach zła jakość wody może powodować wprowadzenie ograniczenia jej w poborze $\mathrm{z}$ ujęcia lub też przerwanie poboru wody.

Jeżeli nie da .się wyeliminować przypadków, z reguły o losowym charakterze, pojawienia się okresów, w których występuje krótkotrwałe przekroczenie wartości normatywnych jakości wody uzdatnionej, co praktyka eksploatacyjna wielokrotnie ujawnia, to należy wprowadzić ograniczenia czasu trwania i częstości takich awaryjnych sytuacji. Trzeba ustalić zarazem granice przekroczeń wartości normatywnych jakości wody do picia. Wprowadzenie takich kryteriów stworzy podstawę do dodatkowych zabezpieczeń [2]. Celem przedstawionej metodyki jest w istocie ograniczenie sytuacji, w których $\mathrm{w}$ wodociagu pojawia się $\mathrm{w}$ krótkich odcinkach czasu uzdatniona woda, lecz o nieodpowiedniej w stosunku do norm jakości, mająca nieznacznie podwyższone, tj. ponadnormatywne stężenie zanieczyszczeń $\mathrm{z}$ jednoczesnym limitowaniem czasu trwania takiego stanu. 


\section{Metoda określenia wskaźników niezawodności dla wody do picia w aspekcie jej fizyczno-chemicznej jakości}

\subsection{Zalożenia metody}

Jako kryterium zanieczyszczenia wody do picia przyjęto stężenia zanieczyszczeń odpowiadające poszczególnym wskaźnikom fizycznochemicznym jej składu. Następnie dokonano podziału wskaźników zawartych w obowiązującym w Polsce normatywie na trzy grupy, kierując się przy tym ich szkodliwością na organizm człowieka [3] [4].

Grupa A obejmuje wskaźniki stanowiące o przydatności wody do picia. Znajduje się tutaj między innymi: barwa, mętność, żelazo, mangan, siarczany i chlorki, dla których przyjmuje się, że okresowe i ograniczone przekroczenia stężeń normatywnych nie zagrażają zdrowiu człowieka.

Grupa B obejmuje wskaźniki stanowiące o istotnym stopniu zagrożenia zdrowia człowieka. Znajdują się tutaj między innymi: formy azotu i fosforu, fluorki, ChZT, $\mathrm{pH}$.

Grupa C obejmuje wskaźniki stanowiące o toksycznym zagrożeniu dla organizmu człowieka. Znajdują się tu między innymi: metale, ciężkie, fenol, cyjanki, DDT i jego metabolity.

Jak można zauważyć, wskaźniki grupy A dotyczą zanieczyszczeń najmniej szkodliwych dla organizmu człowieka, natomiast wskaźniki grupy $\mathrm{C}$ obejmują substancje mające kancerogenny wpływ na organizmy żywe.

Dla wszystkich wskaźników z omówionych grup wprowadzono jedno wspólne pojęcie wskaźnika przekroczenia normy jakości wody do spożycia oznaczonego symbolem W. Stanowi on kryterium oceny zawodności Zakład Uzdatniania Wody (ZUzW) w aspekcie jakości wody do spożycia. Wskaźnik ten zdefiniowany jest następująco:

$$
W=\frac{S-S_{n o r}}{S_{\max }-S_{n o r}}
$$

gdzie:

W - wskaźnik przekroczenia normy jakości wody do spożycia (odnoszony do konkretnego wskaźnika fizyczno-chemicznego wody),

S - stwierdzone stężenie danego wskaźnika fizyczno--chemicznego wody do picia, większe od wartości normatywnej obowiązującej w Polsce,

$\mathrm{S}_{\max }$ - maksymalne dopuszczalne stężenie danego wskaźnika fizycznochemicznego wody do spożycia, przyjęte za danymi Państwowego 
Zakładu Higieny $(\mathrm{PZH})$-("Kryteria tolerancji zawartości w wodzie do picia substancji chemicznych oraz ilości drobnoustrojów wskaźnikowych z 1978 roku"),

$\mathrm{S}_{\text {nor }}$ - dopuszczalne stężenie danego wskaźnika fizyczno--chemicznego wody do picia zgodnie z rozporządzeniem [5].

Z definicji przyjęto, że dla:

$\mathrm{S} \leq \mathrm{S}_{\text {nor }} \quad \mathrm{W}=0$

$\mathrm{S} \geq \mathrm{S}_{\max } \quad \mathrm{W}=1$

Wartości dopuszczalne $\mathrm{W}$ zawierają się w przedziale od 0 do 1, tzn.:

- $\mathrm{W}=0$ - jakość wody zadowalająca, woda ma parametry jakościowe lepsze od wartości progowych, które podaje normatyw,

- $\mathrm{O}<\mathrm{W}<1$-jakość wody nie odpowiada normatywowi, dopuszcza się jednak krótkotrwałe okresy pojawiania się wody o takiej jakości, czas trwania takiego stanu jest ograniczony i określony w dalszej części pracy,

- $\mathrm{W}=1.0$ - jakość wody jest nie do przyjęcia i zachodzi bezwzględnie konieczność wyłączenia ujęcia i ZUzW z eksploatacji celem niedopuszczenia jej do odbiorców.

Stężenia $\mathrm{S}_{\max }$ są szczególnie trudne do ustalenia dla ludzi. Dawka szkodliwa zależy od wielu cech biologicznych organizmu, między innymi od stopnia przyzwyczajenia, wrodzonej wrażliwości lub odporności, szybkości wchłaniania. Wydaje się, że przyjęcie wartości stężeń $\mathrm{S}_{\max }$ według wspomnianego zalecenia PZH jest przy dobowym spożyciu wody przez człowieka wynoszącym $2.5 \mathrm{dm}^{3}$ i dodatkowo przy ograniczeniu czasu spożywania przyjęciem bardzo ostrożnym.

\subsection{Opis metody}

W tabeli 1 podano propozycję podziału wodociągów na kategorie ze względu na niezawodność jakości składu fizyczno-chemicznego wody do spożycia i przeznaczonej na potrzeby gospodarcze.

Prawdopodobieństwo tego, że stężenie zanieczyszczeń przekroczy stężenie normatywne, jest różne dla odmiennych stopni tego przekroczenia. Przedstawiona metoda umożliwia uwzględnienie różnego stopnia przekroczenia stężeń normatywnych oraz wag, które stanowią prawdopodobieństwa zajścia tych przekroczeń. Rozważania przeprowadzono w odniesieniu do jednostki czasu równej 1 rok. Stopień przekroczenia stężenia normatywnego określa wskaźnik przekroczenia normy jakości wody do spożycia W, które- 
go wartości progowe przyjęto arbitralnie. W metodzie przyjęto częstość $\mathrm{C}_{\mathrm{i}}$ występowania okresów, w których pojawić się mogą wartości progowe $\mathrm{W}_{\mathrm{p}}$ $\left(\mathrm{W}_{\mathrm{p}}=0.05,0.1,0.3,0.5,0.7\right)$. Prawdopodobieństwo zaistnienia tych okresów można wyznaczyć z zależności:

$$
P_{i}=\frac{C_{i} T_{i}}{365}
$$

gdzie:

i - numer kolejny rozpatrywanego okresu, w którym występują wartości $\mathrm{O}<$ $\mathrm{W}_{\mathrm{i}}<1.0, \mathrm{i}=1,2, \ldots$,

$\mathrm{T}_{\mathrm{i}}-$ czas trwania i-tego okresu.

Dla stanów, w których zachodzi warunek $\mathrm{W}=0$, tj. dla okresów, w których nie występują przekroczenia danego wskaźnika w stosunku do normatywu, możemy napisać:

$$
P_{0}=1-\sum_{i} P_{i}
$$

Czynnikiem przedstawiającym zawodność ZUzW w odniesieniu do jakości dostarczanej do wodociagu komunalnego wody jest stężenie danego wskaźnika zanieczyszczenia ponad wartość normatywną a określoną pośrednio przez wartość W. Zawodność uogólnioną wyznacza stosunek wartości oczekiwanej przekroczeń wskaźnika $\mathrm{W}$. (przypadki, gdy $0<\mathrm{W}<1$ ) oznaczonej symbolem $\mathrm{E}(\mathrm{W})$ do wartości granicznej tego przekroczenia, tj. dla W $=1$, i wynosi ona:

$$
U_{u}=E \underline{(W)}
$$

Odpowiednio, uogólniony wskaźnik niezawodności wynosi:

$$
K_{u}=1-U_{u}
$$

przy czym 


$$
W(\underline{W})=\frac{\sum_{i=1}^{2} P_{i} W_{i}}{\sum_{i=0}^{2} P_{i}} ; i=0,1,2
$$

Obliczone $\mathrm{w}$ ten sposób wartości $\mathrm{K}_{\mathrm{u}}$ zestawiono $\mathrm{w}$ tab. 1 . Z punktu widzenia praktyki inżynierskiej interesująca jest znajomość prawdopodobieństwa tego, że ZUzW dostarczać będzie w dowolnej chwili wodę odpowiadająca normie. Wartość ta dotyczy przypadku $\mathrm{W}=0$ i równa się $\mathrm{P}_{0}$.

Interpretacja informacji zawartych $w$ tab. 1 jest następująca (rys. 1). Rozpatrzmy kategorię I, przypadek obliczeniowy A oraz $0<\mathrm{W} \leq 0,3$. Przekroczenie normatywnej wartości rozpatrywanego zanieczyszczenia $\mathrm{z}$ grupy $\mathrm{A}$, mieszczące się $\mathrm{w}$ przedziale $0<\mathrm{W} \leq 0,3$ może wystapić nie częściej niż 10 razy w roku, a czas trwania każdego z takich przypadków nie może przekraczać 0,33 doby tj. $8 \mathrm{~h}$. Wskaźnik $\mathrm{W}_{1}$ oznacza wartość progową $\mathrm{W}_{\mathrm{p}}=0,3$, a $\mathrm{P}_{1}$ prawdopodobieństwa zajścia wszystkich przypadków łącznie. Wartość $\mathrm{K}_{\text {udop. }}$ odnosi się do całej grupy przypadków, a więc dla $\mathrm{W}=0,0<\mathrm{W} \leq 0,3$, oraz $0,3<\mathrm{W} \leq 0,5$. Posługiwanie się tab. wskazuje na konieczność obliczenia dla każdego ZUzW wartości wskaźników $\mathrm{K}_{\mathrm{u}}$ i $\mathrm{P}_{0}$ oraz sprawdzenia, czy jest spełniona nierówność:

$$
K \geq K_{w}
$$

gdzie:

$\mathrm{K}$ - rozpatrywany wskaźnik $\mathrm{K}_{\mathrm{u}}$ lub $\mathrm{P}_{0}$ (osobno obliczony dla ZUzW), $\mathrm{K}_{\mathrm{w}}-$ dopuszczalna jego wartość według tab. ( $\left.\mathrm{K}_{\mathrm{udop} .}, \mathrm{P}_{\text {0dop., }} \mathrm{P}_{\mathrm{dop} .}\right)$.

Jeżeli nierówność (7) nie jest spełniona, to ZUzW nie spełnia proponowanych wartości i powinien być modernizowany. Alternatywnym rozwiązaniem może być zapewnienie wprowadzenia do obsługi ZUzW odpowiednich służb zdolnych do szybkiego reagowania na naruszenie warunków normatywnych. W takich przypadkach służby te zdecydowałyby o czasowym wyłączeniu ZUzW z eksploatacji. 


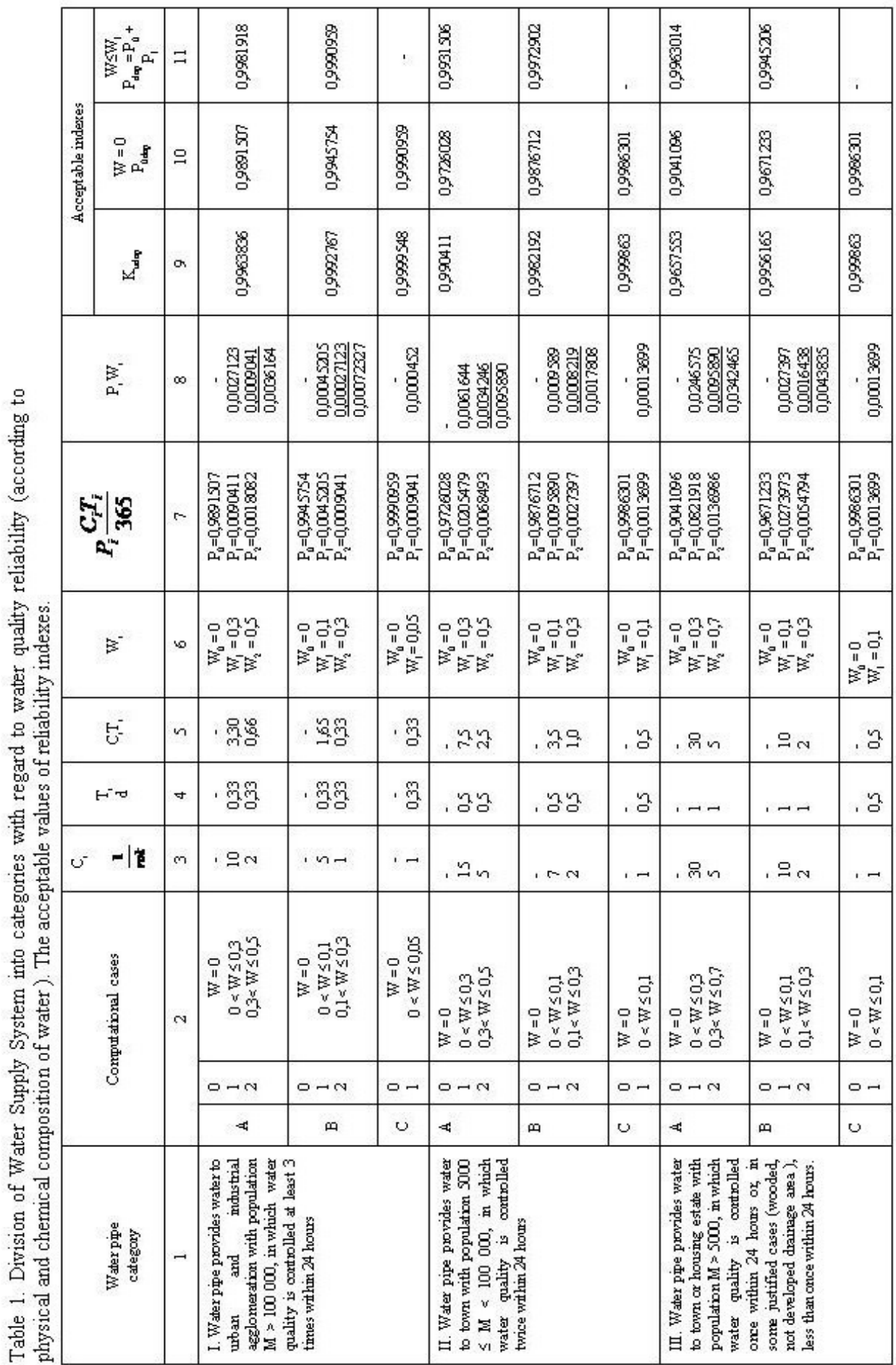




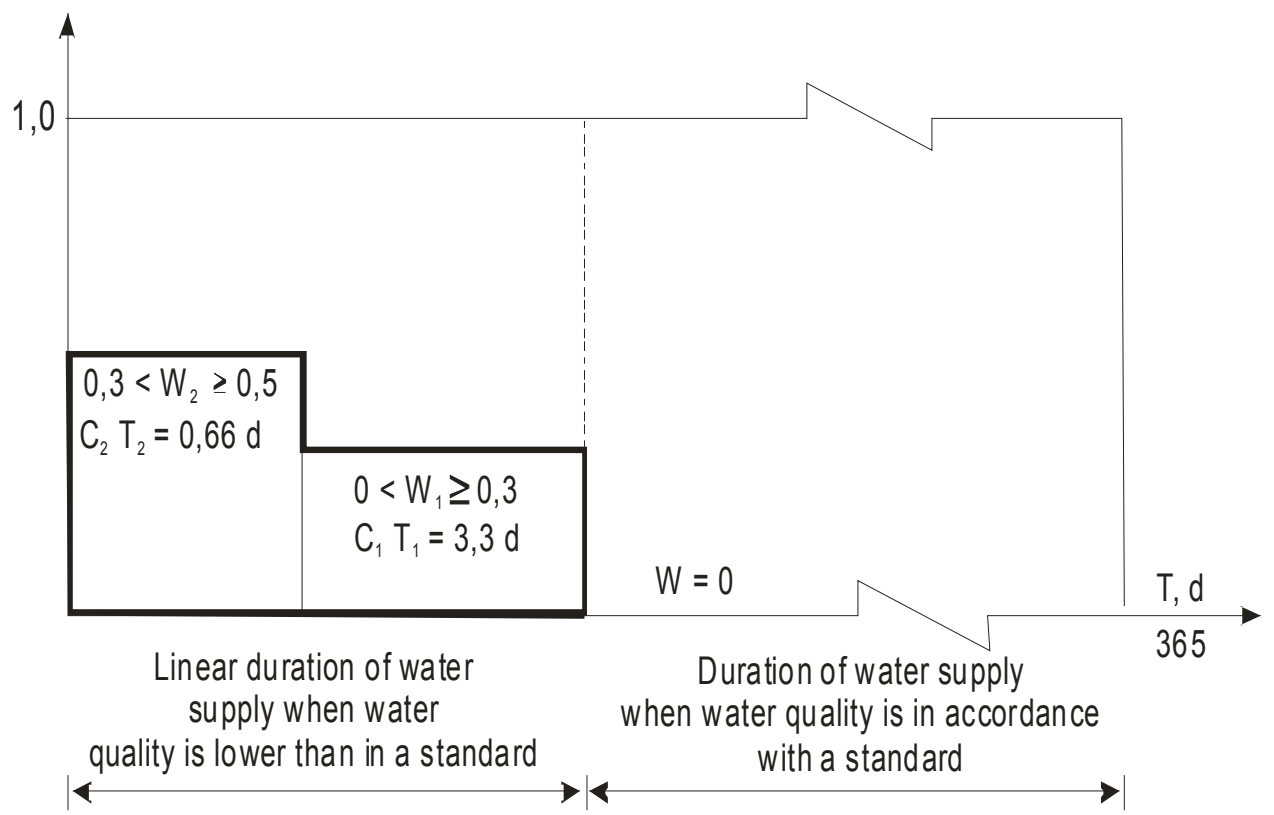

Rys. 1. Histogram częstości występowania stanów jakości wody do spożycia dla kategorii IA według proponowanego podziału.

\section{Podsumowanie}

- Obiektywna rzeczywistości w funkcjonowaniu ZUzW są różnego rodzaju zdarzenia niepożądane, które powodują pogorszenie jakości wody (produktu finalnego) i obniżają poziom niezawodności dostawy wody z wodociagu publicznego, a niekiedy wpływają w istotny sposób na bezpieczeństwo konsumentów wody.

- Przedstawiona tu koncepcja nie umniejsz w niczym ważności normatywu jakości wody, który sprawdzony w ciagu wielu lat jego stosowania wydaje się być uzasadniony, co jednak nie zmienia faktu, że jest on wyrazem aktualnych tendencji i będzie zapewne korygowany, W miarę jak narastać będzie rozpoznanie całego problemu. Wydaje się, że wprowadzenie proponowanego rozwinięcia istniejącego normatywu stałoby się bodźcem do: 
- stosowania bardziej elastycznych technologii oraz pewnej mocy rezerwowej w ZUzW,

- stosowania skuteczniejszej i częstszej kontroli jakości wody, aby zapewnić spełnienie warunków podanych w tab. 1. Zawarte w tab. 1 wartości wskaźników należy uważać za pierwszą próbę realizacji tak postawionego zadania.

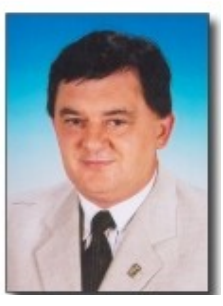

Prof. dr hab. Inż. Janusz Ryszard Rak w roku 1976 ukończył studia na Wydziale Inżynierii Środowiska Politechniki Krakowskiej. Stopień doktora nauk technicznych uzyskał w 1986 r., stopień doktora habilitowanego w 1994 r., a w 2006 r. otrzymał tytuł naukowy profesora nauk technicznych. Pracuje na stanowisku profesora zwyczajnego w Politechnice Rzeszowskiej. Jest kierownikiem Katedry Zaopatrzenia w Wodę i Odprowadzania Ścieków. Specjalność - niezawodność i bezpieczeństwo systemów komunalnych. 
